\title{
Mineral Contents of Selected Pearl Millet (Pennisetum glaucum (L.) R. Br.) X Elephant Grass (Pennisetum purpureum (Schum.)) Interspecific Hybrids of Nigerian Origin
}

\author{
Ekemini Edet Obok ${ }^{1}$ \\ ${ }^{1}$ Department of Crop Science, University of Calabar, Calabar, Nigeria \\ Correspondence: Ekemini Edet Obok, Department of Crop Science, University of Calabar, Calabar, PMB 1115, \\ Cross River State, Nigeria. E-mail: kemi_rex@yahoo.com
}

Received: February 13, 2013 Accepted: March 13, 2013 Online Published: March 15, 2013

doi:10.5539/jps.v2n2p22

URL: http://dx.doi.org/10.5539/jps.v2n2p22

\begin{abstract}
A study was conducted to analyse the mineral constituents of generated $\mathrm{F}_{1}$ interspecific hybrids of Pennisetum species grown in Nigeria. Non-reciprocal crosses were made involving two elephant grass selections (pollen parents), S.13 and S.15, and five cultivated pearl millet genotypes (female parents) namely Maiwa 25-2, Maiwa 28-1, Maiwa 94-2, Dauro and male sterile Gero A. Genetic incompatibility and poor combining ability in some interspecific crosses among Pennisetum species of Nigerian origin were reported. Crosses between Gero A and the elephant grass selections gave rise to unsuccessful hybrids whereas Maiwa 25-2, Maiwa 28-1, Maiwa 94-2, and Dauro crosses resulted in successful hybrids with promising potentials of improved mineral contents. These hybrids had high phosphorus content and relatively high calcium content above the optimum requirement for dairy production. Amongst the mineral contents determined, magnesium and iron showed the highest $(\mathrm{CV}=$ $32.9 \%)$ and the least $(\mathrm{CV}=11.0 \%)$ variations, respectively. The overall results revealed existing genetic potentials in Nigerian pearl millet genotypes to improve (through hybridization) elephant grass in terms of mineral richness as a complement to its high herbage yields. However, strong recommendations for rational ruminant-feeding trials using these promising interspecific hybrids point at further evaluation studies.
\end{abstract}

Keywords: Pennisetum species, pearl millet, elephant grass, hybridization, mineral content, herbage yield

\section{Introduction}

The tropical grass species, pearl millet (Pennisetum glaucum (L.) R. Br.) and elephant grass (Pennisetum purpureum (Schum.)) are both of the family Poaceae. The species belonging to the genus, Pennisetum, constitute a heterogeneous assemblage ranging from diploids to octoploids with either sexual or apomictic reproductive behaviour having annual, biennial or perennial life cycle (Martel, de Nay, Siljak-Yakovlev, Brown, \& Sarr, 1997). Three germplasm pools are recognizable in Pennisetum species (Harlan \& de Wet, 1971). The primary pool, which contains all cultivated, weedy and wild diploids that are freely cross-fertile; secondary pool is solely P. purpureum, a vigorous perennial tetraploid species of African origin and the tertiary pool which contains more distantly related Pennisetum species of various ploidies which do not naturally interbreed with the primary pool (Dujardin \& Hanna, 1989). On one hand, pearl millet, a dual-purpose species and the most widely grown of all millet types, is primarily processed as grain cereal for human consumption while the forage is fed to ruminants (Gulia, Wilson, Carter, \& Singh, 2007). On the other hand, elephant grass is one of the most important tropical forage grasses in the tropics (Pereira, 1994). It is a unique grass species with high dry matter, which sustains its utilization for direct animal grazing and as a feed complement during drought periods. The interspecific hybridization of elephant grass $(2 \mathrm{n}=4 \mathrm{x}=28)$ and cultivated pearl millet $(2 \mathrm{n}=2 \mathrm{x}=14)$ genotypes is genetically expected to result in the production of infertile triploid hybrids $(2 n=3 x=21)$ with improved forage yields. After several attempts, hybridization projects involving pearl millet and elephant grass have been exploited. The selection and suitability of the resulting hybrids as forage materials have usually been evaluated based on their agronomic performances. In no particular order, most of the agronomic data usually considered include, different dates of planting, the number of days to flowering, plant height at different harvest intervals, number of tillers per plant at harvesting, leaf:stem ratio and forage dry matter yield. However, the roles of mineral elements are overly significant in pasture production. Phosphorus, for example, is present in proteins and nucleic acids, which is critically important in energy transfer processes. Calcium is important in cell growth, cell 
division, and cell wall formation activities. The actions of potassium as a catalyst for enzyme reactions important in protein synthesis, translocation, and storage of starch cannot be over-emphasized. Magnesium sits as the central atom of the chlorophyll molecule that is essential in the formation of fats and sugars. Phosphorylation, activation of enzymes, and carbohydrate metabolism is supported by manganese while iron serves as an important component of many enzyme activities and a catalyst in the synthesis of chlorophyll (National Research Council (NRC), 1980). The mineral content of forage grass interspecific hybrids often receives very little to no attention in pasture breeding and improvement programmes. The study was therefore aimed at assessing the mineral composition of interspecific hybrids between representative genotypes of five Nigerian pearl millet types and two high-yielding local selections of elephant grass. The information from this study will guide plant breeders involved in the identification and selection of promising Pennisetum interspecific hybrids with improved mineral richness in addition to the primarily desired agronomic attributes like fresh herbage and dry matter yields.

\section{Materials and Methods}

The biological materials studied came from previous forage breeding work at the Plant Breeding Unit of the Department of Agronomy, University of Ibadan, Nigeria.

\subsection{Hybridization}

Seeds of different pearl millet genotypes were planted in two rows each at a distance of $90 \mathrm{~cm} \times 90 \mathrm{~cm}$ in June 2009 and non-reciprocal crosses (Griffing, 1956) were made in September 2009 following anthesis. The elephant grass selections served as the male parents. After four to six weeks, mature seeds were extracted, sieved and cleaned of impurities from panicles of the pollinated pearl millet plants. The seeds were later stored separately with labels indicating the parents and dates of crosses and harvest.

\subsection{Seed Viability Tests}

Through germination tests, assessments of the success rates of the crosses were carried-out in May 2010. Fifty seeds from each of the crosses were placed inside petri dishes on damp cotton wools, soaked in sterile water. These seeds were monitored for seven days and only successfully germinated hybrids with purple coleoptiles were tagged and moved into seed boxes in the nursery. These seedlings were nursed for four weeks in the screen house.

\subsection{Field Evaluation}

After the acclimatization of the selected seedlings in the nursery, they were transplanted to the field at a spacing of $90 \mathrm{~cm} \times 90 \mathrm{~cm}$ for individual plant evaluation. This took place in June/July 2010 when rainfalls have stabilized. The experimental field was located in the Agronomy Department Crop garden ( $\left.7^{\circ} 27^{\prime} \mathrm{N} ; 3^{\circ} 54^{\prime} \mathrm{E}\right), 218$ $\mathrm{m}$ above sea level, University of Ibadan, Nigeria. The transplanted plants were first harvested, at $30 \mathrm{~cm}$ height above ground, at ten weeks after transplanting. This duration and stubble height was allowed to ensure uniform re-growth and re-establishment of the cutback plants. A second harvest was made at six weeks after the first harvest.

\subsection{Chemical and Statistical Analyses}

The following mineral contents (in percentages) were determined; phosphorus (P), calcium (Ca), potassium (K), magnesium $(\mathrm{Mg})$, manganese $(\mathrm{Mn})$ and iron $(\mathrm{Fe})$. Representative forage samples were obtained from seven plants of each of the crosses. The samples obtained were oven-dried for $2-4$ days at $70^{\circ} \mathrm{C}$ to attain constant dry weight. The dry samples were later milled and subjected to chemical analysis (Association of Official Analytical Chemists (AOAC), 1995) for mineral content determination. Descriptive analysis was done using GenStat $\left(13^{\text {th }}\right.$ Edition) for Windows. These results were presented as mean values with class limits set at $95 \%$ confidence interval.

\section{Results and Discussion}

The physical and chemical soil properties of the experimental field prior to planting are presented in Table 1 . The preliminary soil analysis was necessitated because micronutrients present in the soil are accessed by livestocks in the forages they feed on (Khan, Ashraf, Ahmad, Mustafa, \& Danish, 2007) which is also a relative indication of the soil nutrient uptake ability of the forage plant. The soil was slightly acidic with characteristic low nitrogen, relatively high level of organic matter and high level of available phosphorus. The high level of available phosphorus is an associated attribute of slightly acidic soils and this has an implication for phosphorus release in the soil for plant uptake. In addition, available phosphorus as well as nitrogen has reportedly strong influences on the growth and yield of forage grasses (Rao, Friesen, \& Osaki, 1999). However, where there is a limitation, 
moisture availability could greatly affect the dry matter yield of forage grass than fertilization (Volesky \& Berger, 2010). The exchangeable bases ranged from $0.37 \mathrm{cmol} \mathrm{kg}^{-1}$ to $5.36 \mathrm{cmol} \mathrm{kg}^{-1}$. These low values were ascribed to soil erosion and the leaching of soil nutrients from the topsoil, which are the distinguishing features of soils in the humid lowland tropics. Mineral deficiencies, both for pasture and for animal growth, are more prevalent in the highly leached soils of the tropics, which are prone to water erosion; this is not a recurring challenge in the management of temperature pastures (Humphreys, 2005).

Table 1. Chemical and physical characteristics of the experimental soil

\begin{tabular}{cc}
\hline Soil characteristic* & Value \\
\hline pH $\left(\mathrm{H}_{2} \mathrm{O}\right)$ & 6.6 \\
Organic carbon $(\mathrm{g} / \mathrm{kg})$ & 14.9 \\
Total nitrogen $(\mathrm{g} / \mathrm{kg})$ & 0.75 \\
Available phosphorus $(\mathrm{mg} / \mathrm{kg})$ & 41.2 \\
Trace elements & 14.8 \\
Iron $(\mathrm{mg} / \mathrm{kg})$ & 2.58 \\
Copper $(\mathrm{mg} / \mathrm{kg})$ & 129 \\
Manganese $(\mathrm{mg} / \mathrm{kg})$ & 14.08 \\
Zinc $(\mathrm{mg} / \mathrm{kg})$ & \\
Exchangeable bases & 0.59 \\
Potassium $(\mathrm{cmol} / \mathrm{kg})$ & 3.53 \\
Calcium $(\mathrm{cmol} / \mathrm{kg})$ & 5.36 \\
Magnesium $(\mathrm{cmol} / \mathrm{kg})$ & 0.37 \\
Sodium $(\mathrm{cmol} / \mathrm{kg})$ &
\end{tabular}

Particle size

$\begin{array}{cc}\text { Clay }(\mathrm{g} / \mathrm{kg}) & 48 \\ \text { Silt }(\mathrm{g} / \mathrm{kg}) & 98 \\ \text { Sand }(\mathrm{g} / \mathrm{kg}) & 858 \\ \text { ural class }(\mathrm{USDA} \dagger) & \text { Loamy sand }\end{array}$

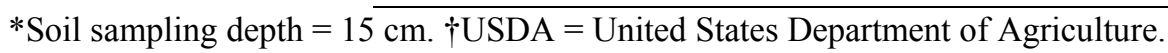

The chemical analysis (Table 2) revealed that the total phosphorus content of the hybrids ranged from $0.35 \%$ (Maiwa 94-2 x S.15) to $1.49 \%$ (Maiwa 25-2 x S.13) and $0.83 \%$ and $0.78 \%$ for S.13 and S.15, respectively. The phosphorus content values of Maiwa 25-2 x S.13 and Maiwa 28-1 x S.15 were above the mean upper confidence limit of all the entries. Only the phosphorus content of Maiwa 94-2 x S.15 hybrid was below the lower confidence limit. The highest calcium content among the hybrids was $0.30 \%$, found in Maiwa 25-2 x S.13 while the lowest calcium content of $0.18 \%$ was recorded by Maiwa $28-1$ x S.13. The elephant grass selections both recorded $0.17 \%$ calcium contents. All the hybrids, except Maiwa $25-2$ x S.13 (0.30\%), had calcium content values that were within the lower $(0.19 \%)$ and upper $(0.24 \%)$ confidence limits. The calcium contents recorded by the elephant grass selections (both having $0.17 \%$ calcium content) and Maiwa $28-1$ x S.13 hybrid (0.18\%) were below the lower confidence limit. The minimum calcium and phosphorus requirements generally recommended for the maintenance of domestic livestock under range conditions are $0.32 \%$ and $0.17 \%$, respectively and beef cattle require $0.16 \%$ to $0.60 \%$ calcium and $0.16 \%$ to $0.43 \%$ phosphorous of dry matter ration, depending on sex, age, and growth condition (NRC, 1970). Given these recommendations, the hybrids were highly rich in phosphorus content and relatively rich in calcium content. This shows the unique ability of these hybrids to effectively absorb and retain available phosphorus from the soil. Though phosphorus is very critical in dairy diets (Hersom, 2010), calcium and phosphorus have integrated functions in animals and the absorption as well as intake of calcium and phosphorus must be adequate since the absorption of these two important minerals depends on their combined ratio. The balance between calcium and phosphorus ratio in 
forage grasses has attracted enormous research interest from forage breeders. Often bred against is the wide calcium to phosphorus ratio, which is an undesirable attribute of forage grasses. In the hybrids evaluated, the calcium to phosphorus ratio ranged from 1:1.5 (Maiwa 94-2 x S.15) to 1:5.7 (Maiwa 28-1 x S.15) while the elephant grass selections had ratios of 1:4.9 (S.13) and 1:4.6 (S.15). Only Maiwa 94-2 x S.15 hybrid fell within the desirable Ca:P range of 2:1 to 1:2 recommendations on ruminant nutrition (Bogdan, 1977). The relatively wide ratios recorded by other hybrids were common among tropical forages reported by Dietz, Udall and Yeager (1962) above which there could be impaired skeletal structures and reduced physiological activities in ruminants.

A high level of potassium in forage grasses is also not desirable. High potassium content in forage grasses potentially exacerbates the condition of elevated serum magnesium content in animal blood (hypermagnesaemia) (Humphreys, 2005). Potassium content in all the hybrids ranged from $0.44 \%$ to $0.52 \%$ except in Maiwa $94-2 \times$ S.13 (0.53\%) and Maiwa 25-2 x S.13 (0.34\%) hybrids, which were above and below the upper and lower confidence limits, respectively. The overall mean potassium content of the eight hybrids was $0.48 \%$ while that of the two elephant grass selections was $0.50 \%$, though S. 13 recorded the highest potassium content of $0.52 \%$ over S.15 with $0.47 \%$. The average potassium content of S.13 was higher than that of the hybrids by $8.3 \%$ and similar to Maiwa 94-2 x S.13 hybrid. There was a moderate variation in the potassium content of all the plants and this was indicated by an $11.5 \% \mathrm{CV}$ value.

The magnesium contents of the two elephant grass selections, S.13 $(0.15 \%)$ and S.15 $(0.16 \%)$ were similar. Variation among the hybrids and the elephant grass selections in magnesium content was relatively high with a $\mathrm{CV}$ value of $32.9 \%$. The highest magnesium content was recorded by Maiwa $25-2$ x S.13 hybrid $(0.30 \%)$ and the lowest from Maiwa 94-2 x S.15 hybrid (0.12\%). Overall, the hybrids were similar to their respective male parents in terms of magnesium content except the hybrids of Maiwa 25-2 female parent, which had magnesium content above the upper confidence limit $(0.20 \%)$. The lower and upper confidence limits of manganese content for all the genotypes were set by the two elephant grass selections, S.15 (0.004\%) and S.13 (0.005\%), respectively. Maiwa 28-1 x S.15 fell below the confidence limit whereas all Dauro hybrids had manganese contents above the upper confidence limit. Other hybrids had same manganese content with S.13 (0.004\%). Of all the mineral content considered; the lowest values were recorded for manganese and iron contents. All the hybrids with S.13 parent, except those of Dauro, had high iron contents compared with hybrids of S.15 male parent. Similarly, the iron content of S.13 male parent was lower than that of S.15 male parent. Maiwa 25-2 xS.13, Maiwa 94-2 x S.13 hybrids and S.13 male parent had iron contents that were below the lower confidence limit $(0.032 \%)$. However, Dauro x S.13 hybrid recorded the highest iron content $(0.042 \%)$ and had the highest manganese content as well.

Table 2. Mineral contents of P.glaucum x P.purpureum $\mathrm{F}_{1}$ hybrids and P.purpureum selections

\begin{tabular}{|c|c|c|c|c|c|c|c|}
\hline $\begin{array}{c}\text { Genotype } \\
\text { Hybrid }\end{array}$ & Phosphorus & Calcium & $\begin{array}{c}\text { Calcium:Phophorus } \\
\%\end{array}$ & Potassium & Magnesium & Manganese & Iron \\
\hline Maiwa $25-2$ x S. 13 & 1.49 & 0.30 & $1: 5.0$ & 0.34 & 0.30 & 0.004 & 0.031 \\
\hline Maiwa $25-2$ x S.15 & 1.00 & 0.18 & $1: 5.6$ & 0.49 & 0.21 & 0.004 & 0.034 \\
\hline Maiwa 28-1 x S.13 & 0.77 & 0.22 & $1: 3.5$ & 0.50 & 0.13 & 0.004 & 0.035 \\
\hline Maiwa $28-1$ x S. 15 & 1.20 & 0.21 & $1: 5.7$ & 0.51 & 0.16 & 0.003 & 0.037 \\
\hline Maiwa 94-2 x S.13 & 1.01 & 0.20 & $1: 5.1$ & 0.53 & 0.13 & 0.004 & 0.029 \\
\hline Maiwa 94-2 x S.15 & 0.35 & 0.22 & $1: 1.5$ & 0.44 & 0.12 & 0.004 & 0.036 \\
\hline Dauro x S.13 & 0.92 & 0.24 & $1: 3.8$ & 0.50 & 0.14 & 0.007 & 0.042 \\
\hline Dauro x S.15 & 0.83 & 0.23 & $1: 3.6$ & 0.50 & 0.16 & 0.006 & 0.035 \\
\hline \multicolumn{8}{|l|}{ Elephant grass } \\
\hline S.13 & 0.83 & 0.17 & $1: 4.9$ & 0.52 & 0.15 & 0.005 & 0.031 \\
\hline S.15 & 0.78 & 0.17 & $1: 4.6$ & 0.47 & 0.16 & 0.004 & 0.033 \\
\hline $\mathrm{CL}_{(0.05)}$ & $0.70-1.13$ & $0.19-0.24$ & $1: 3.7-1: 4.7$ & $0.44-0.52$ & $0.13-0.20$ & $0.004-0.005$ & $0.032-0.037$ \\
\hline CV (\%) & 32.5 & 17.2 & & 11.5 & 32.9 & 24.9 & 11 \\
\hline
\end{tabular}


Generally, variation in mineral content of forage grasses depends upon the type of soil and the prevailing environmental conditions (Beeson \& Matrone, 1976; McDowell, Conrad, \& Hembry, 1993). An earlier report by Kaynogo-Male and Thomas (1975) showed a wide range of nutrient concentrations among tropical grasses. In the present study, the potassium and magnesium levels were similar to the report of Premaratne and Premalal (2006) with a range of $0.42 \%$ to $0.47 \%$ and $0.21 \%$ to $0.36 \%$, respectively. In addition, the respective critical levels of $0.004 \%$ (Anonymous, 1984) and $0.005 \%$ (Viets \& Lindsey, 1973) for manganese and iron have already been established for forage grasses; these levels agreed closely with the manganese levels obtained from the hybrids in this study. McDowell and Arthington (2005) previously found that the tolerable level of iron in forage grasses is $0.10 \%$ and Ahmad, Ejaz, Khan, Gondal, Fardous, Hussain, Sher, Valeem and Ullah (2010) reported that iron is the least toxic of all the essential trace minerals for livestock. However, the study revealed relatively high concentrations of iron contents in all the hybrids. Since forage is identified as the primary source of nutrients for livestock (McDowell, 1992); it is therefore crucial, from the preliminary results obtained from this study, that the mineral composition of any selected forage grass species is considered in all breeding programmes for forage improvement.

\section{Conclusions}

The determination of only the ash content of forage grass materials does not provide sufficient information to rely solely upon whereas the amount of the respective minerals present often gives information that is more useful. This study was primarily aimed at giving an insight into the identification of promising interspecific hybrids of Pennisetum species as suitable forage grass materials based on their mineral composition in addition to the traditional convention of only considering agronomic characteristics. It was however evident that reliable information of this sort, which is seldom used, would serve as a complementary aid in the selection of Pennisetum hybrids with exceptional forage yields and rich mineral composition profile. The problems of mineral deficiency will therefore be mitigated through forage grass breeding improvement programmes directed towards the maximization of mineral uptake and the maintenance of nutrient concentrations in plant tissue considered as suitable forage materials. To further this study, animal trials were suggested to ensure that ruminant livestock have not just been fed with 'high-yielding' forage grass species but are given the recommended levels of mineral nutrients needed in their diet/ration for optimum growth, development and reproduction.

\section{Acknowledgement}

I immensely thank Emeritus Professor Michael E. Aken'Ova, University of Ibadan, Ibadan, for his contributions during the study.

\section{References}

Ahmad, K., Ejaz, A., Khan, Z. I., Gondal, S., Fardous, A., Hussain, A., ... Ullah, S. (2010). Evaluation of dynamics of iron and manganese from pasture to buffaloes: A case study at rural livestock farms. Pakistan Journal of Botany, 42(5), 3415-3421. Retrieved from www.pakbs.org/pjbot/PDFs/42(5)/PJB42(5)3415.pdf

Anonymous. (1984). Nutrient requirements of domestic animals. In Nutrient requirements of beef cattle (6th ed.). Washington, DC: National Academy of Sciences.

Association of Official Analytical Chemists (AOAC). (1995). Official Methods of Analysis (16th ed.). Washington, DC: AOAC.

Beeson, K. C., \& Matrone, G. (1976). The soil factor in nutrition: Animal and human, nutrition and clinical nutrition. New York, NY: Marcel Dekker.

Bogdan, A. V. (1977). Tropical pasture and fodder plants. New York, NY: Longman.

Dujardin, M., \& Hanna, W. W. (1989). Developing apomictic pearl millet: characterization of a $\mathrm{BC}_{3}$ plant. Journal of Genetics and Breeding, 43, 145-151. Retrieved from link.springer.com/content/pdf/10.1007\%2FBF00222460.

Dietz, D. R., Udall, R. H., \& Yeager, I. E. (1962). Chemical composition and digestibility by mule deer of selected forage species. Colorado Department of Game and Fish. Technical Publications 14. Colorado: Cache La Poundre Range.

Griffing, B. (1956). Concept of general and specific combining ability in relation to diallel crossing system.Australian Journal of Biological Sciences, 9, 463-493.

Gulia, S. K., Wilson, J. P., Carter, J., \& Singh, B. P. (2007). Progress in grain pearl millet research and market development. In J. Janick \& A. Whipkey (Eds.), Issues in new crops and new uses: edible oilseeds, grains, 
and grain legumes (pp. 196-203). Virginia: American Society for Horticultural Science (ASHS) Press.

Harlan, J. R., \& de Wet, J. M. (1971). Toward a rational classification of cultivated plants. Taxonomy, 20, 509-517. http://dx.doi.org/10.2307/1218252

Hersom, M. (2010). Basic nutrient requirements of beef cows. AN190 series of the Animal Science Department, Florida Cooperative Extension Service, Institute of Food and Agricultural Sciences. Gainesville: University of Florida.

Humphreys, L. R. (2005). Tropical pasture utilization. Cambridge: Cambridge University Press.

Kayongo-Male, H., \& Thomas, J. W. (1975). Mineral composition of some tropical grasses and their relationships to the organic constituents and estimates of digestibility. East African Agricultural and Forestry Journal, 40, 428-438.

Khan, Z. I., Ashraf, M., Ahmad, K., Mustafa, I., \& Danish, M. (2007). Evaluation of micro-minerals composition of different grasses in relation to livestock requirements. Pakistan Journal of Botany, 39(3), 719-728. Retrieved from www.pakbs.org/pjbot/PDFs/39(3)/PJB39(3)719.pdf

Martel, E., de Nay, D., Siljak-Yakovlev, S., Brown, S., \& Sarr, A. (1997). Genome size variation and basic chromosome number in pearl millet and fourteen related Pennisetum species. The Journal of Heredity, 88, 139-143. http://dx.doi.org/10.1093/oxfordjournals.jhered.a023072

McDowell, L. R. (1992). Minerals in animal and human nutrition. San Diego: Academic Press.

McDowell, L. R., \& Arthington, J. D. (2005). Minerals for grazing ruminants in tropical regions (5th ed.). Gainesville: University of Florida.

McDowell, L. R., Conrad, J. H., \& Hembry, F. G. (1993). Minerals for grazing ruminants in tropical regions (2nd ed.). Gainesville: University of Florida.

National Research Council (NRC). (1970). Nutrient requirements of beef cattle. Washington, DC: National Academy of Sciences.

National Research Council (NRC). (1980). Mineral tolerance of domestic animals. Washington, DC: National Academy of Sciences.

Premaratne, S., \& Premalal, G. G. C. (2006). Hybrid Napier (Pennisetum purpureum x Pennisetum americanum) var. CO-3: a resourceful fodder grass for dairy development in Sri Lanka. The Journal of Agricultural Sciences, 2(1), 22-33.

Pereira, A. V. (1994). Germoplasma e diversidade genetic do capim-elefante. Simpósio sobre capim-elefante. Empresa Brasileira de Pesquisa Agropecuária (EMBRAPA) - Centro Nacionalde Pesquisa de Gado de Leite (CNPGL), Juiz de Fora. pp. 1-11.

Rao, I. M., Friesen, D. K., \& Osaki, M. (1999). Plant adaptation to phosphorus-limited tropical soils. In M. Pessarakli (Ed.), Handbook of plant and crop stress (pp. 61-95). New York, NY: Marcel.

Viets, F. G., \& Lindsay, W. L. (1973). Testing soils for zinc, copper, manganese and iron. In L. M. Walsh \& J. Beaton. (Eds.), Soil testing and plant analysis (pp. 153-172). Madison: Soil Science Society of America (SSSA).

Volesky, J. D., \& Berger, A. L. (2010). Forage production with limited irrigation. In NebGuide 2012, Range and forage pasture management (pp. 1-4). Lincoln: University of Nebraska. 